\title{
Os Estudos para a Paz - Tendências e debates
}

José Manuel Pureza

\section{(2) OpenEdition}

\section{Journals}

Edição electrónica

URL: http://journals.openedition.org/rccs/1330

DOI: $10.4000 /$ rccs. 1330

ISSN: 2182-7435

\section{Editora}

Centro de Estudos Sociais da Universidade de Coimbra

Edição impressa

Data de publição: 1 junho 2005

Paginação: 03-04

ISSN: 0254-1106

\section{Refêrencia eletrónica}

José Manuel Pureza, «Os Estudos para a Paz - Tendências e debates 》, Revista Crítica de Ciências

Sociais [Online], 71 | 2005, posto online no dia 01 outubro 2012, consultado o 22 setembro 2020. URL : http://journals.openedition.org/rccs/1330 ; DOI : https://doi.org/10.4000/rccs.1330 


\section{Os Estudos para a Paz - Tendências e debates}

Este número da Revista Crítica de Ciências Sociais reúne um conjunto de reflexões sobre a área dos Estudos para a Paz. Pretendemos, através delas, propiciar um olhar plural sobre o desenvolvimento deste campo analítico $e$ discursivo - escassamente acolbido entre nós - e dar conta dos principais debates que o vêm atravessando. Num tempo de disseminação de práticas e discursos de violência directa, estrutural ou cultural com intensidades inéditas, o presente volume dá corpo à busca de fundamentos teóricos densos para a prevalência de um princípio alternativo: o de uma cultura de paz.

O registo de conjunto que se colhe dos textos agora apresentados é o de que os Estudos para a Paz constituem um dominio acesamente disputado entre uma perspectiva confinada à resolução de problemas e uma perspectiva crítica de denúncia das causas estruturais dos conflitos e de busca, a esse nivel, de alternativas de paz. Como lembra Håkan Wiberg, esta ambiguidade está inscrita no próprio código genético da disciplina: a tensão entre "investigação para a pacificação" e "investigação para a emancipação", ou entre "investigação liberal para a paz" e "investigação crítica para a paz" marca, desde os primórdios, o debate epistemológico neste domínio. De algum modo, essa tensão teórica exprime-se na diferenciação entre investigação sobre a paz e investigação para a paz, com a primeira a situar-se prioritariamente numa lógica de tecnicidade e de procedimentalismo e a segunda a assumir a filiação deste saber no terreno da teoria crítica.

Ainda que o peso respectivamente assumido seja objecto de discussão, a orientação normativa e a complexidade conceptual são marcas identificadoras dos Estudos para a Paz. Por elas passa, há décadas, o projecto de formação de um conhecimento que se assume em contraponto à matriz realista da investigação sobre relações internacionais e sobre a guerra como seu facto social maior. Martínez Guzmán sublinha, aliás, que esse cânone realista é, afinal, tributário de um falso realismo, pois que não considera as relações humanas em toda a sua complexidade. Com efeito, o ponto de partida imprescindivel para um entendimento exigente e crítico dos Estudos para a Paz é o de que a sua razão de ser é a possibilidade de transformar por meios pacíficos, em todas as escalas, as dinâmicas de violência e que, para isso, havemos de reconhecer quer as nossas competências para organizar de modo violento as nossas 
relações, quer as nossas competências para organizar as nossas relações com base na ternura, na justiça ou na sustentabilidade.

Os Estudos para a Paz não são pois, como reclama Martínez Guzmán, expressão de idealismo ingénuo. Antes visam identificar e analisar a diversidade de mecanismos geradores de violência, sempre na perspectiva de lhes contrapor dinâmicas e instrumentos de paz. Johan Galtung, reconhecidamente um dos vultos maiores da Peace Research, propõe-nos uma leitura macro-social e macro-histórica desta simetria entre dimensões da violência e experiências de paz. Para esse efeito, e usando aquilo que designa por formação social indo-europeia, Galtung analisa e ilustra a multidimensionalidade quer da violência - directa, estrutural e cultural -, quer da paz.

O aprofundamento dos debates fundadores dos Estudos para a Paz passa hoje, fundamentalmente, por dois dominios. O primeiro é a geografia da paz e da violência. Dele nos dão conta os artigos de Tatiana Moura e de Rodrigo Tavares. Os conceitos de "novíssimas guerras" e de "novíssimas pazes", sugeridos por aquela autora, procuram sintetizar novos quadros espaciais de conflitualidade, em que a fronteira entre criminalidade e guerra se esfuma, suscitando uma centralidade mais viva de actores subalternizados nos discursos tradicionais sobre os conflitos, como as mulheres. É também de geografia da paz que fala Rodrigo Tavares, ao ensaiar uma complexa árvore conceptual para o estudo da regionalização da paz e do caso da Europa em particular. O segundo dominio de aprofundamento actual dos Estudos para a Paz é o debate epistemológico. José Manuel Pureza e Teresa Cravo advertem para os riscos de cooptação dos Estudos para a Paz pelas estruturas de regulação corrente do sistema internacional e sugerem como pólos de resgate da perspectiva crítica neste campo a adopção de uma paz sustentável como referência e a descolonização da agenda dos Estudos para a Paz, isto é, quer do quadro teórico quer das políticas nele fundadas.

Este numero inclui ainda dois importantes contributos de Elísio Estanque e de Hermes Costa para o estudo da actualidade das lutas laborais e sindicais. Os novos desafios do internacionalismo e da recomposição da estrutura de classes determinam reconfigurações do movimento sindical que importa analisar. E, ainda aqui, é de paz que se fala. Daquela que se consolida em relações sociais de justiça.

José Manuel Pureza 